\title{
Commonly used medicinal plants in N. Mualcheng, Mizoram, India
}

\author{
Lalbiakngheti Tlau*, Lucy Lalawmpuii \\ Department of Life Sciences, Pachhunga University College, Mizoram University, Aizawl 796001
}

\begin{abstract}
Medicinal plants are the source of therapeutic agents in traditional medicines. The present study investigated Mizo traditional medicinal plants commonly used and available at N. Mualcheng, a village in Mizoram, India. The most important plants in terms of usage and availability as 10 species belonging to 9 families, of which Asteraceae contributes two species (such as Blumea lanceolaria, Acmella sp.), while Fabaceae, Acanthaceae, Costaceae, Orobanchaceae, Proteaceae, Elaeagnaceae, Smilacaceae and Plantaginaceae contribute one species each such as Mimosa pudica, Thunbergia grandiflora, Chamaecostus cuspidatus, Aeginetia indica, Helicia robusta, Elaeagnus caudata, Smilax perfoliata and Plantago asiatica respectively. An important feature of these medicinal plants is that some of them are used for complex diseases including kidney problem, gastric ulcer and diabetes mellitus.
\end{abstract}

Received 1 December 2020 Accepted 16 December 2020

*For correspondence: beetlau87@gmail.com

Contact us: sciencevision@outlook.com

Keywords: N. Mualcheng, medicinal plants, traditional knowledge, disease, kidney problem.

\section{Introduction}

Mizoram is known to have one of the highest species richness in medicinal plants and the uses and applications are varied from one place to another. ${ }^{1}$ Before the times when modern pharmaceuticals and synthetic drugs were even introduced in Mizoram, plants had been used as medicinal remedies in search of a cure for diseases from the far past by our ancestors. From the times when each village had a chief, one of the most important tasks given to the local physicians, appointed by chief, was discovering new medicines suitable for the disease as having a good physician was the pride of the village. Furthermore, those discoveries have been still validated and extended till today. Even though the modern world and technology kicked in the state over a century, some hearts, exclusively the villagers', has been won by herbal medicines over synthetic ones since the plants used as medicines are easily available to them and relatively less expensive while some with the think of zero money spending on medicines since they do not afford them. Undoubtedly, the true potential of these plants and compounds of their medicinal properties has not yet discovered and identified in many plants, but still many users choose to continue using them as they have less side effects on the human body. ${ }^{2}$

Rai and Lalramnghinglova reported from Mizoram in 2010 that there were 159 ethnomedicinal plants belonging to 134 genera and 56 families from different sites such as tropical forest, home gardens, roadsides and Mizoram University campus which significantly shows the importance and popularity of folk medicine in Mizo society. ${ }^{3}$ However, site-specific covering individual village or district has not been documented. This is important as geographical variants and differences in 
application of some plants are evident across the state.

N. Mualcheng, East Lungdar Block of Serchhip district, is located in the northeastern part of Mizoram with a distance of about $160 \mathrm{~km}$ away from Aizawl, the capital city of the state. As per Census 2011, it has a population of 1423 with about 264 households. ${ }^{4}$ Most of the villagers are dependent on slash-and-burn cultivation while the only government job there is teaching at schools. This village also has some specific plants which have been practiced and mode of uses that has been inherited from their former inhabitants of the village. In addition to that, when people get injured, the most effective first aid is derived from plants, which are just near at hand such as Thunbergia grandiflora and other plants like Mikania micrantha, Eupatorium odoratum, etc., which were not included in this study.

\section{Methodology}

The ethno botanical survey was conducted in November 2020. The folklore information was collected from one informant, the village elder, who is known as the longest user of traditional medicine in the village through interview and discussion. Out of 38 medicinal plants surveyed, only 10 plants, which are easily available, were selected for the present study.

\section{Results and Discussion}

The present study showed that people in $\mathrm{N}$.

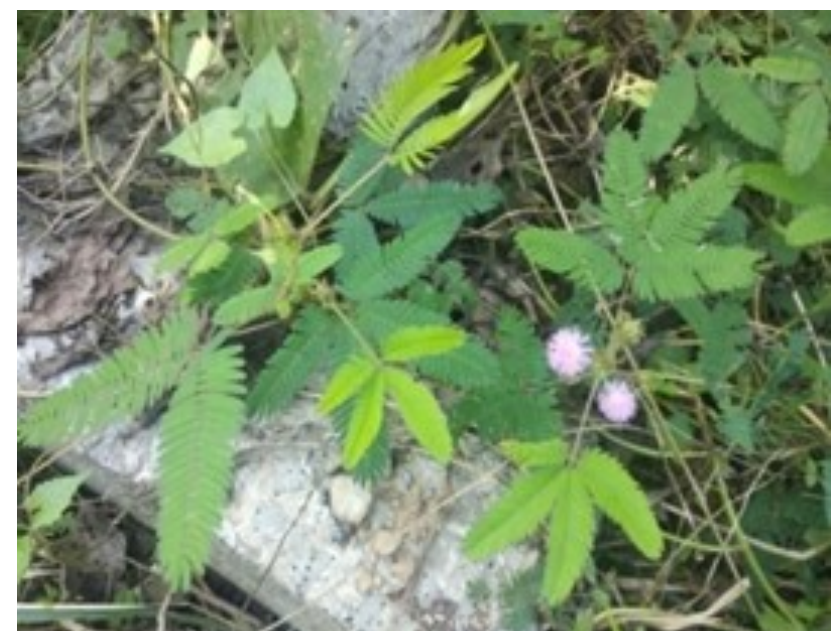

Figure 1 | Hlonuar

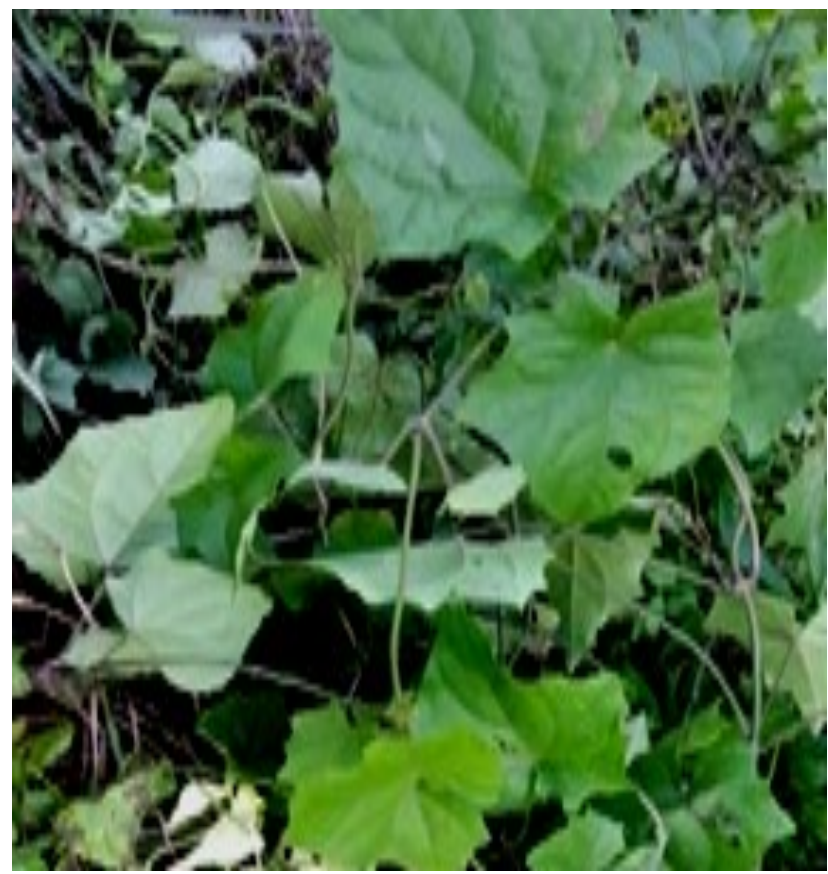

Figure 3 | Vako

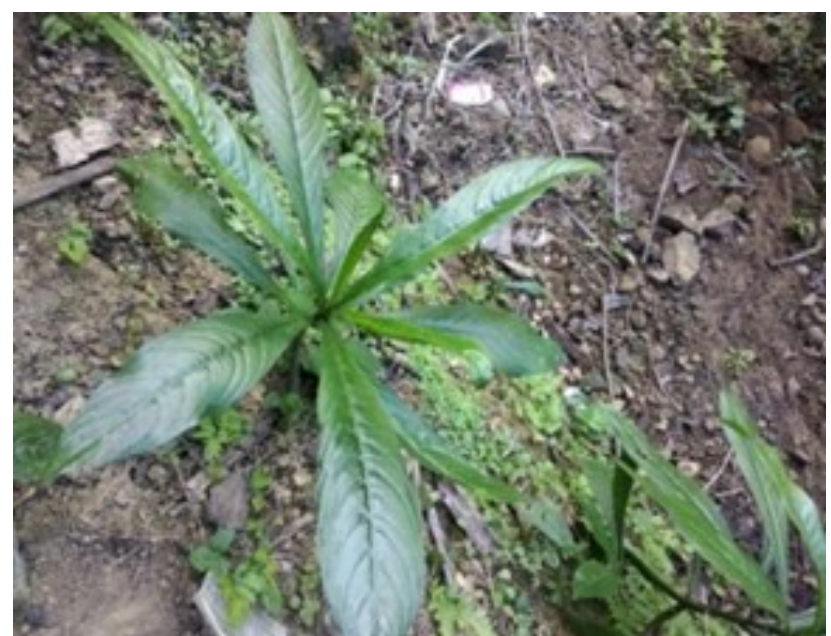

Figure 2 | Buarze

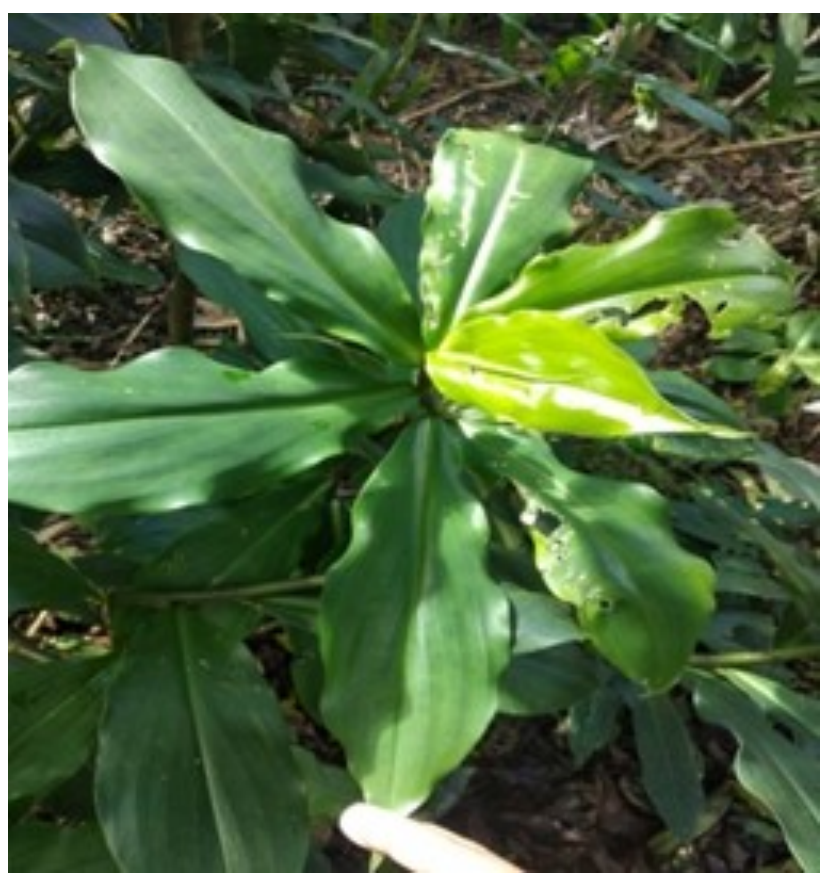

Figure 4 | Sumbul chi khat 


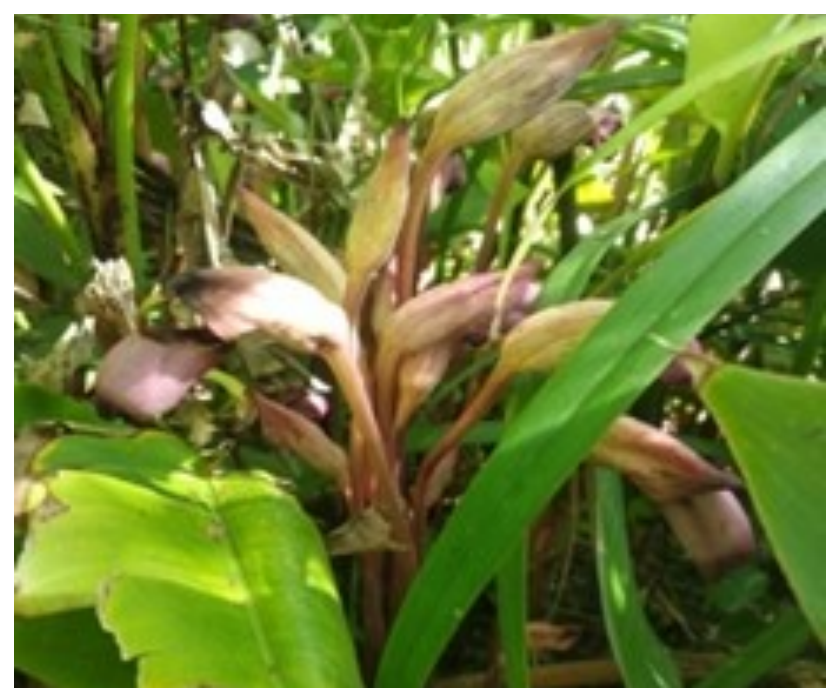

Figure 5 | Sangharvaibel

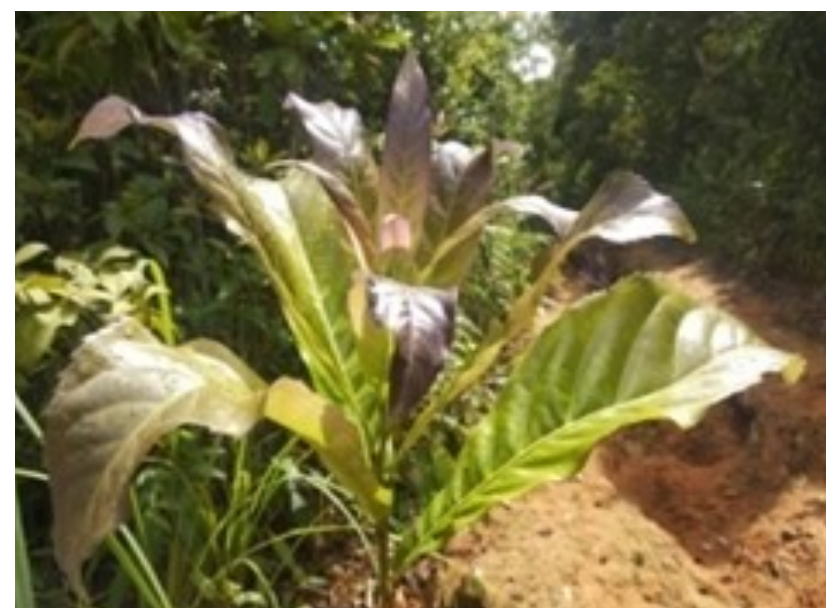

Figure 7 | Pasaltakaza

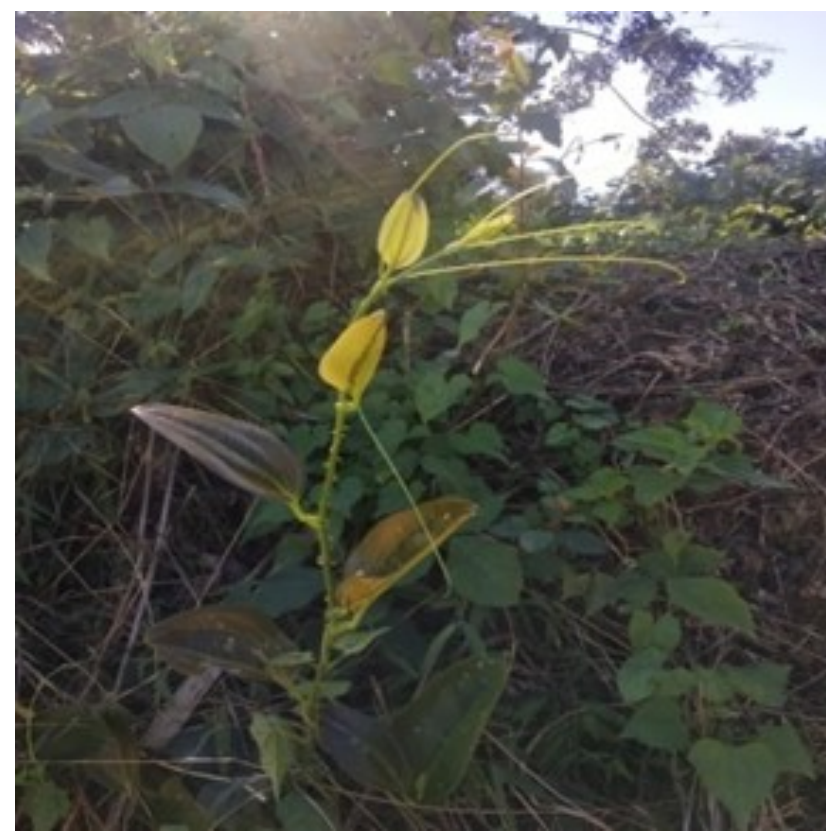

Figure 9 | Kaiha

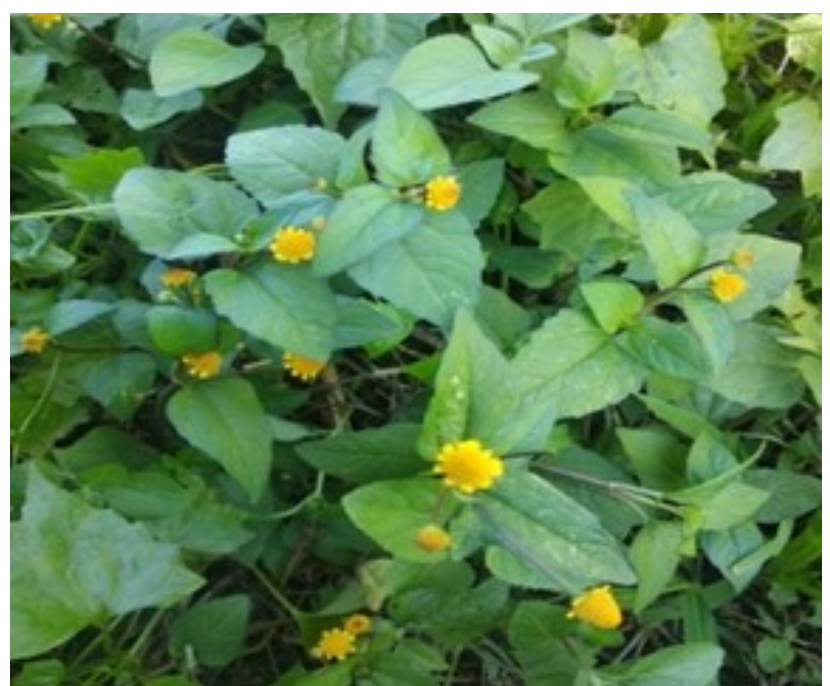

Figure 6 | Ankasate

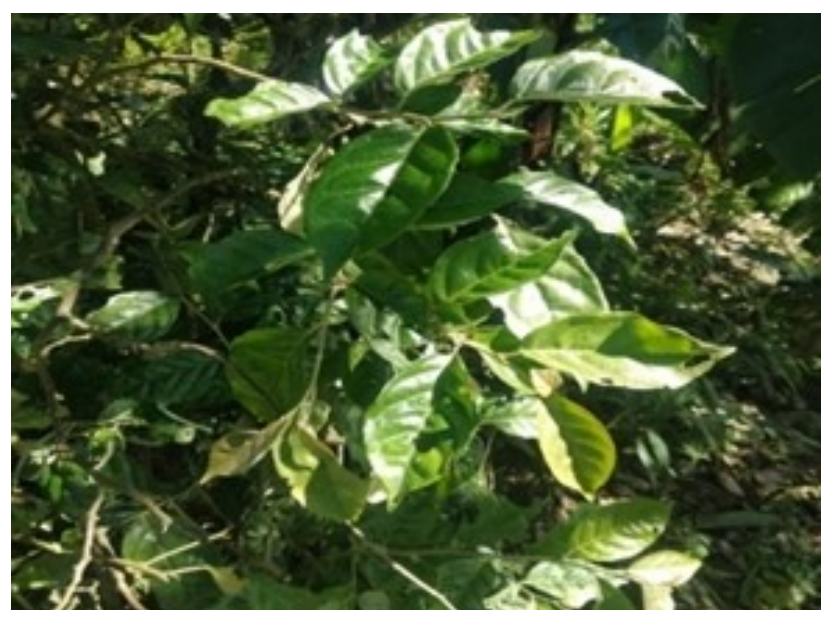

Figure 8 | Sârzûk

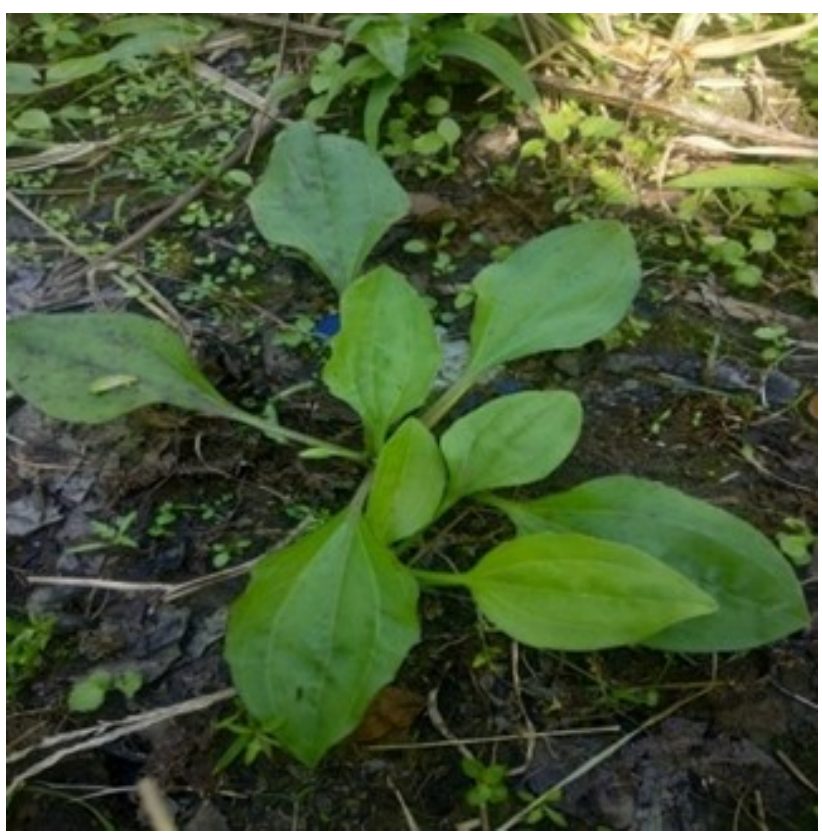

Figure 10 | Kelbaan 
Table 1 | List of medicinal plants used in N. Mualcheng.

\begin{tabular}{|c|c|c|c|c|c|c|}
\hline Local name & $\begin{array}{l}\text { English } \\
\text { name }\end{array}$ & Family & $\begin{array}{l}\text { Scientific } \\
\text { name }\end{array}$ & $\begin{array}{l}\text { Parts } \\
\text { used }\end{array}$ & $\begin{array}{l}\text { Mode of } \\
\text { uses }\end{array}$ & Medicinal uses \\
\hline Hlonuar & $\begin{array}{l}\text { Touch- me- } \\
\text { not }\end{array}$ & Fabaceae & $\begin{array}{l}\text { Mimosa pudica } \\
\text { L. }\end{array}$ & $\begin{array}{l}\text { Whole } \\
\text { plant }\end{array}$ & Decoction & $\begin{array}{l}\text { Kidney problems, } \\
\text { jaundice }\end{array}$ \\
\hline Buarze & $\begin{array}{l}\text { Lanceleaf } \\
\text { Blumea }\end{array}$ & Asteraceae & $\begin{array}{l}\text { Blumea } \\
\text { lanceolaria } \\
\text { (Roxb.) Druce }\end{array}$ & $\begin{array}{l}\text { Whole } \\
\text { plant }\end{array}$ & Decoction & $\begin{array}{l}\text { Stomach ulcers, } \\
\text { wounds and cut }\end{array}$ \\
\hline Vako & $\begin{array}{l}\text { Blue trumpet } \\
\text { vine }\end{array}$ & Acanthaceae & $\begin{array}{l}\text { Thunbergia } \\
\text { grandiflora } \\
\text { Roxb. }\end{array}$ & $\begin{array}{l}\text { Whole } \\
\text { plant }\end{array}$ & $\begin{array}{l}\text { Direct } \\
\text { application, } \\
\text { decoction }\end{array}$ & $\begin{array}{l}\text { Cut and wounds, } \\
\text { gastric ulcer }\end{array}$ \\
\hline $\begin{array}{l}\text { Sumbul chi } \\
\text { khat }\end{array}$ & Insulin plant & Costaceae & $\begin{array}{l}\text { Chamaecostus } \\
\text { cuspidatus } \\
\text { (Nees \& Mart.) } \\
\text { C.Specht \& } \\
\text { D.W.Stev. }\end{array}$ & $\begin{array}{l}\text { Leaves } \\
\text { and } \\
\text { roots }\end{array}$ & Decoction & $\begin{array}{l}\text { Blood sugar } \\
\text { reducer }\end{array}$ \\
\hline Sangharvaibel & $\begin{array}{l}\text { Forest ghost } \\
\text { flower }\end{array}$ & Orobanchaceae & $\begin{array}{l}\text { Aeginetia indica } \\
\mathrm{L} \text {. }\end{array}$ & $\begin{array}{l}\text { Whole } \\
\text { plant }\end{array}$ & Decoction & Mumps \\
\hline Ankasate & $\begin{array}{l}\text { Toothache } \\
\text { plant }\end{array}$ & Asteraceae & Acmella sp. & $\begin{array}{l}\text { Leaves } \\
\text { and } \\
\text { flowers }\end{array}$ & $\begin{array}{l}\text { Eaten raw } \\
\text { or cooked }\end{array}$ & $\begin{array}{l}\text { toothache, } \\
\text { enterobiasis }\end{array}$ \\
\hline Pasaltakaza & & Proteaceae & $\begin{array}{l}\text { Helicia robusta } \\
\text { (Roxb.) R. Br. Ex } \\
\text { Wall. }\end{array}$ & Bark & Decoction & $\begin{array}{l}\text { Stomachache, } \\
\text { Kidney problems }\end{array}$ \\
\hline Sârzûk & Silverberry & Elaeagnaceae & $\begin{array}{l}\text { Elaeagnus } \\
\text { caudata Schltdl }\end{array}$ & Leaves & Decoction & $\begin{array}{l}\text { Stomachache, } \\
\text { gynecologic } \\
\text { problem, } \\
\text { expelling } \\
\text { placenta }\end{array}$ \\
\hline Kaiha & Greenbriar & Smilacaceae & $\begin{array}{l}\text { Smilax } \\
\text { perfoliata Lour. }\end{array}$ & $\begin{array}{l}\text { Tender } \\
\text { stem } \\
\text { gel } \\
\text { (sap), } \\
\text { root }\end{array}$ & $\begin{array}{l}\text { Direct } \\
\text { application } \\
\text { on skin, } \\
\text { decoction }\end{array}$ & $\begin{array}{l}\text { Scar remover, } \\
\text { Sciatica }\end{array}$ \\
\hline Kelbaan & $\begin{array}{l}\text { Asian } \\
\text { plantain }\end{array}$ & Plantaginaceae & $\begin{array}{l}\text { Plantago } \\
\text { asiatica L. }\end{array}$ & $\begin{array}{l}\text { Whole } \\
\text { plant }\end{array}$ & $\begin{array}{l}\text { Decoction, } \\
\text { Direct } \\
\text { application } \\
\text { on skin }\end{array}$ & $\begin{array}{l}\text { Gastric ulcer, } \\
\text { diabetes, cuts } \\
\text { and wounds, } \\
\text { kidney problems }\end{array}$ \\
\hline
\end{tabular}

Mualcheng commonly use 10 medicinal plants belonging to 9 families. Two species belong to Asteraceae while there was one species each in Fabaceae, Acanthaceae, Costaceae, Orobanchaceae, Proteaceae, Elaeagnaceae, Smilacaceae and Plantaginaceae.

Mimosa pudica L. (Figure 1) is one of the widely used medicinal plants and claimed to have high ayurvedic properties to treat different types of diseases. ${ }^{5}$ The same ethno-botanical used of $M$. pudica in jaundice is also reported from central India. ${ }^{6}$ Some research also proved that this plant has high antimicrobial properties. ${ }^{7}$ It is also found that M. pudica is effectively used for nephrolithiasis treatment. $^{8}$
Blumea lanceolaria (Roxb.) (Figure 2) seems to have high anti-inflammatory and wound healing properties. Druce Blumea of different species like $B$. balsamifera is effectively used as traditional medicine in Indonesia, Myanmar and in other parts of Southeast Asia to treat peptic ulcers as this plant consists of flavonoids which help to increase the amount of gastric mucus glycoprotein and inhibition of prostaglandin production. ${ }^{9}$

Rai and Lalramnghinglova (2010) reported the same practice of using vako (Thunbergia grandiflora, Figure 3) in cuts and wounds in other parts of Mizoram as it has an antiseptic property. This report also mentioned that decoction of the leaves is taken 
as diabetes medicine. ${ }^{3}$ Medicinal uses of this plant in stomach problems is reported from South west Bengal and Sonaghati district, Uttar Pradesh, India. ${ }^{10,11}$

It is interesting to note that the insulin plant, Chamaecostus cuspidatus (Figure 4) is already known for its antidiabetic activity. The experiments and investigations performed in experimental diabetic rats by the leaves extract of C. cuspidatus, also known as Costus igneus, C. cuspidatus, C. pictus, Globba cuspidatus, revealed the presence of steroids and alkaloids which then showed significant antidiabetic activity. ${ }^{12,13}$

The application of decoction of Aeginetia indica (Figure 5) rhizome is reported from western and other part of Mizoram., ${ }^{34}$ The experiment claimed that among six commonly used herbal decoctions thought to benefit the liver, Aeginetia indica decoction has the highest inhibitory effect on hepatitis $C$ virus (HCV) infection by reducing NS5A phosphorylation at serine $235 .^{15}$

There are several reports on Acmella sp. (Figure 6) as a commonly used medicinal plant for many dental problems such as periodontitis and toothache treatment by chewing flowers and leaves, and for this a common name, toothache plant, has been given. It also has an effective antifungal property against the fungi Cryptococcus neoformans, Microsporum gypseum and antibacterial properties against Staphylococcus aureus, S. epidermidis, Escherichia coli, etc. ${ }^{16,17}$ The uses of Acmella sp. to treat enterobiasis (itching of anal area caused by pinworm infection) is also reported from the studies of pinworms and other root canal pathogens like Escherichia faecalis, Staphylococcus sp. Streptococcus sp., etc. ${ }^{18}$

The record of medicinal plants and uses in some papers showed that the usage of decoction of bark and leaves of the Helicia robusta (Figure 7) for treating stomachache and kidney problems in different parts of Mizoram has been reported, ${ }^{19,20}$ and the uses of its root decoction for stomach ulcer is also recorded from other studies within Mizoram. ${ }^{21}$

Decoction of Elaeagnus caudata leaves (Figure 8), particularly taken as medicine for menstruation and gynecological problem, is widely used in all parts of Mizoram and the utilization of fresh root extract diluted with water to prevent miscarriage is also reported from North Cachar hills, Assam. ${ }^{22,23}$

The root and stem of Smilax perfoliata (Figure 9) is taken as anti-cancer and anti-dysenteric remedies as well as in urinary problems. It richly contains antimicrobial and antioxidant properties. ${ }^{24}$ Some reports also claimed that this plant is also used to prevent scars from smallpox. ${ }^{25}$

Plantain plant (Figure 10) is widely used for many medicinal purposes such as wounds, diabetes, acne, etc. as it has an antibacterial property and many important biological activities which includes iridoid glucosides, phenylethanoid glycosides, flavonoids, terpenoids, phenolic acids and polysaccharides. ${ }^{26}$ Many research and experiments have also been performed on the utilization of this plant and its other species for its antipeptic activity. ${ }^{27}$

\section{Conclusion}

This review clearly shows that the types and uses of medicinal plants has been surveyed, documented and recorded in every corner of Mizoram and the need of more and deeper studies on this field is required to exactly know the truth behind these plants. Moreover, this survey importantly shows that medicinal uses of some plants have not been made known to other places rather than this village which makes it obvious that many more discoveries can be done on scientific basis.

\section{Conflict of interest}

The authors declared no conflict of interest.

\section{References}

1. Rai PK, Lalramnghinglova $H$. Ethnomedicinal plants of India with special reference to an IndoBurma hotspot region: An overview. Ethnobotany Research and Applications. 2011; 18(9):379-429. DOI: 10.17348/era.9.0.379-420

2. Lusweti A, Wabuyele E, Ssegawa P, Mauremootoo J. Thunbergia grandiflora (Blue Thunbergia). BioNET-EAFRINET Keys and Fact Sheets. 2011. Retrieved on 01 November 2020 from https:// keys.lucidcentral.org/keys/v3/eafrinet/weeds/key/ weeds/Media/Html/Thunbergia_grandiflora_ (Blue_Thun-bergia).htm

3. Rai PK, Lalramnghinglova H. Ethnomedicinal plant resources of Mizoram, India: Implication of traditional knowledge in health care system. Ethnobotanical Leaflets. 2010; 14(3):274-305.

4. Anonymous. N. Mualcheng. Indian Village Directory. www.villageinfo.in

5. Joseph B, George J, Mohan J. Pharmacology and traditional uses of Mimosa pudica. International Journal of Pharmaceutical Sciences and Drug Research. 2013; 5(2):41-44.

6. Janghel V, Patel P, Chandel SS. Plants used for the treatment of icterus (jaundice) in Central India: A review. Annals of Hepatology. 2019; 18(5):658-72.

7. Lakshmibai R, Amirtham D. Antimicrobial activity of Mimosa pudica thorns. International Research Journal of Pharmacy. 2018; 9(6):202-206. DOI: http:// dx.doi.org/10.7897/2230-8407.096117

8. Das S, Vasudeva N, Sharma S. Kidney disorders and management through herbs: A Review. Journal of Phytopharmacology. 2019; 8(1):21-27. 
9. Nugroho AE, Wijayanti A, Mutmainah M, Susilowati R, Rahmawati N. Gastroprotective effect of combination of hot water extracts of Licorice (Glycyrrhiza glabra), Pulasari stem bark (Alyxiareinwardtii), and Sembung leaf (Blumea balsamifera) against aspirin-induced gastric ulcer model rats. Journal of Evidence-Based Complementary E Alternative Medicine. 2016; 21(4):NP77-84.

10. Tripathi S, Ray S, Mondal AK, Verma NK. Rare ethno medicinal plants of south West Bengal, India with their different medicinal uses: needs conservation. International Journal of Life Sciences Biotechnology and Pharma Research. 2013; 2(2):22503137.

11. Singh AK, Raghubanshi AS, Singh JS. Medical ethnobotany of the tribals of Sonaghati of Sonbhadra district, Uttar Pradesh, India. Journal of Ethnopharmacology. 2002; 81(1):31-41.

12. Bhat V, Asuti N, Kamat A, Sikarwar MS, Patil MB. Antidiabetic activity of insulin plant (Costusigneus) leaf extract in diabetic rats. Journal of Pharmacy Research. 2010; 3(3):608-611.

13. Jyothi AN, Priyanka E, Tony DE, Nadendla RR. Chamaecostus cuspidatus - A short review on anti diabetic plant. Indo American Journal of Pharmaceutical Sciences. 2015; 2(7):1110-1113.

14. Lalfakzuala $R$, Kayang $H$, Lalramnghinglova $H$. Ethnobotanical usages of plants in western Mizoram. Indian Journal of Traditional Knowledge. 2007; 6(3):486-493.

15. Lin CW, Lo CW, Tsai CN, Pan TC, Chen PY, Yu MJ. Aeginetia indica decoction inhibits hepatitis C virus life cycle. International Journal of Molecular Sciences. 2018; 19(1):208.

16. Srinath $S$, Lakhshmi T. Therapeutic potential of Spilanthes acmella - A dental note. International Journal of Pharmaceutical Sciences Review and Research. 2014; 25(1): 151-156.

17. Purushothaman Y, Gunaseelan S, Vijayakumar SD. Spilanthes acmella and its medicinal uses - A review. Asian Journal of Pharmaceutical and Clinical Research. 2018; 11(6):45-49.

18. Sathyaprasad S, Jose BK, Chandra HS. Antimicrobial and antifungal efficacy of Spilanthes acmella as an intracanal medicament in comparison to calcium hydroxide: An in vitro study. Indian Journal of Dental Research. 2015; 26(5):528-532. DOI: 10.4103/0970-9290.172081.
19. Lalhmingsangi $\mathrm{K}$, Sahoo UK. Impact of climate change on medicinal plant diversity, indigenous traditional knowledge and utilization pattern in joint forest management areas of Mizoram. In (J Zothanzama, B L Saitluanga, Lalnuntluanga, ST Lalzarzovi, R Zonunsanga, eds) Climate Change: Impact, Adaptation \& Response in the Eastern Himalayas. New Delhi, India: Excel India Publishers. 2018, pp. 67-74. ISBN: 978-93-88237-161.

20. Sharma HK, Chhangte L, Dolui AK. Traditional medicinal plants in Mizoram India. Fitoterapia. 2001; 72(2): 146-161.

21. Khiangte $\mathrm{Z}$, Lalramnghinglova $\mathrm{H}$. Inventorization of indigenous medicinal plants and practices in Mizoram, North-East India. Pleione 2017; 11(2):268 DOI: 10.26679/Pleione.11.2.2017.268-276

22. Lalrinzuali K, Vabeiryureilai M, Jagetia GC. The analysis of antioxidant activity and phenolic contents of selected medicinal plants of Mizoram. Genomics and Applied Biology. 2016; 28:6. DOI: 10.5376/gab.2015.06.0011

23. Rout J, Sajem AL, Nath M. Medicinal plants of North Cachar Hills district of Assam used by the Dimasa tribe. Indian Journal of Traditional Knowledge. 2012; 11(3): 520-527.

24. Borkataky M. Antimicrobial and antioxidant activity of Smilax perfoliate Lour. Der Pharmacia Lettre. 2014; 6(6):246-250.

25. Baruah S, Brahma D, Upadhya P. Phytochemical study of some selected medicinal plants and its ethnobotanical importance to the indigenous communities of Assam. Medicinal Plants. 2018; 10 (2):145-150.

26. Genc Y, Dereli FTG, Saracoglu I, Akkol EK. The inhibitory effects of isolated constituents from Plantago major subsp. major L. on collagenase, elastase and hyaluronidase enzymes: Potential wound healer. Saudi Pharmaceutical Journal. 2020; 28(1):101-106. DOI: 10.1016/j.jsps.2019.11.011

27. Melese E, Asres K, Asad M, Engidawork E. Evaluation of the antipeptic ulcer activity of the leaf extract of Plantago lanceolata L. in rodents. Phytotherapy Research. 2011; 25(8):1174-1180. DOI: 10.1002/ptr.3411. 